\title{
Controlled Trial of Phetharbital, a Non-hypnotic Barbiturate, in Unconjugated Hyperbilirubinaemia
}

\author{
JOHN HUNTER, R. P. H. THOMPSON, M. O. RAKE, ROGER WILLIAMS
}

British Medical fournal, 1971, 2, 497-499

\section{Summary}

Eleven patients with mild unconjugated hyperbilirubinaemia (Gilbert's syndrome) took part in a double-blind cross-over trial of phenobarbitone and phetharbital, a non-hypnotic barbiturate. Significant reductions in plasma bilirubin were observed with both drugs, but six patients complained of sleepiness on phenobarbitone, and phetharbital was preferred by most patients. Phetharbital was also effective in the rare severe unconjugated hyperbilirubinaemia of the Crigler-Najjar syndrome (Type 2). Symptoms attributed to Gilbert's syndrome, including nausea and abdominal pain, were less consistently relieved.

\section{Introduction}

Phenobarbitone has been used to reduce the plasma bilirubin level in patients with congenital unconjugated hyperbilirubinaemia, an effect attributed to induction of the hepatic enzyme bilirubin glucuronyl transferase (Arias et al., 1969; Black and Sherlock, 1970). It may, however, produce drowsiness, which some patients are unable to tolerate. Phetharbital (Pyrictal), a barbiturate with virtually no hypnotic side effects, was originally introduced for the management of epilepsy (Millichap et al., 1960) and has since been shown to have powerful hepatic cnzyme-inducing properties (Kuntzman et al., 1968). In this paper we report a controlled trial of phetharbital and phenobarbitone in patients with the mild unconjugated hyperbilirubinaemia of Gilbert's syndrome and also the effect of phetharbital therapy in one patient with the more severe unconjugated hyperbilirubinaemia of the Crigler-Najjar syndrome, type 2.

\section{Design of Trial}

The seven male and four female patients with Gilbert's syndrome who took part had plasma bilirubin levels varying between 1.2 and $3.2 \mathrm{mg} / 100 \mathrm{ml}$. Other liver function tests, including bromsulphthalein excretion, were normal. Liver biopsies showed normal histological appearances and hyperbilirubinaemia due to a primary haemolytic process was excluded by a ${ }^{31} \mathrm{Cr}$-labelled red cell survival test.

Identical tablets were prepared which contained either phenobarbitone $60 \mathrm{mg}$ or phetharbital $600 \mathrm{mg}$. The latter dose was chosen because when used as an anticonvulsant the dose required is about ten times greater than that of phenobarbitone (Millichap et al., 1960). The patients were started randomly on treatment with one or other drug which was then continued for a period of four weeks. After an interval of six weeks to

Medical Research Council Group on Metabolism and Haemodynamics of Liver Disease, Department of Medicine, King's College Hospital, London S.E.5

JOHN HUNTER, M.B., M.R.C.P., Research Fellow

R. P. H. THOMPSON, B.M., M.R.C.P., M.R.C. Clinical Research Fellow R. P. H. THOMPSON, B.M., M.R.C.P., M.R.C. Clinical Research Fellow M. O. RAKE, B.SC., M.R.C.P., Research Fellow and Honorary Lecturer ROGER W
Physician allow ample time for the effects of the first drug to disappear, the patients were given the second drug for another four-week treatment period. The plasma bilirubin was determined at fortnightly intervals throughout, Michaelsson's method as modified by Thompson (1969) being used. Care was taken to ensure that samples were always obtained at the same time of day. Since the plasma bilirubin varies considerably in patients with Gilbert's syndrome, the mean of at least four determinations before the start of the first treatment period was taken as the patient's "basal" level. It was to this value that the changes after treatment with either phenobarbitone or phetharbital were related.

Each patient recorded on a questionnaire the symptoms which he had experienced during the previous week. Sleepiness was specifically inquired after, as were the symptoms sometimes encountered in Gilbert's syndrome, including abdominal pain, nausea, and tiredness.

\section{Results}

The plasma bilirubin was reduced in every patient by both drugs (Fig. 1) and the decreases compared with the "basal"

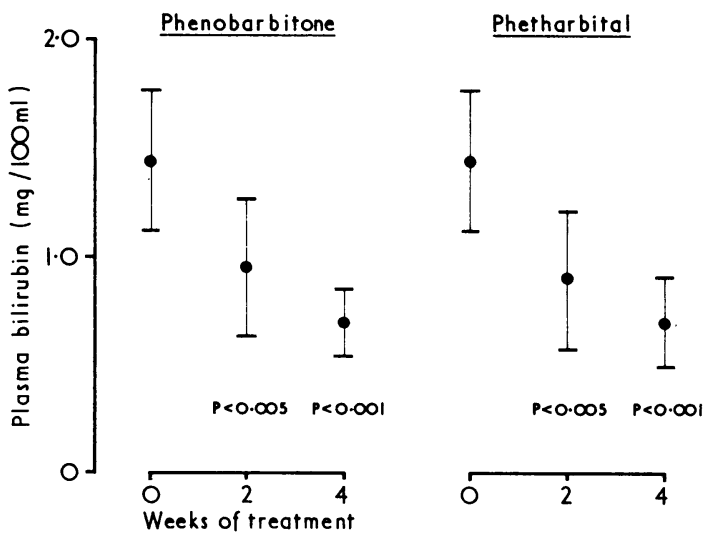

FIG. 1-Mean plasma bilirubin levels in 11 patients with Gilbert's syndrome after two and four wecks' treatment with phenobarbitone or phetharbital.

level were statistically significant at the end of both the second and fourth week of each treatment period $(P<0.005$ and $<0.001$ respectively). For phetharbital the mean percentage fall in plasma bilirubin was $40 \%$ at two weeks and $53 \%$ after four weeks, whereas for phenobarbitone the corresponding figures were $34 \%$ and $53 \%$ respectively. Thus the effect of phetharbital on the plasma bilirubin was the same as that of phenobarbitone, and when treatment with either drug was stopped the plasma bilirubin returned to the original level in two to four weeks.

Analysis of the symptom questionnaire showed that seven patients preferred phetharbital, two phenobarbitone, and two had no preference (see Table). Six patients complained of sleepiness while taking phenobarbitone, but only one on phetharbital. Symptoms of nausea and abdominal pain were relieved in two patients by phetharbital and in a further two by phenobarbitone. In five patients symptoms persisted even when plasma bilirubin levels were considerably reduced. 
Analysis of Symptom Questionnaire

\begin{tabular}{|c|c|c|c|c|c|c|c|}
\hline \multirow{2}{*}{$\begin{array}{l}\text { Case } \\
\text { No. }\end{array}$} & \multirow{2}{*}{ Symptoms before Trial } & & \multicolumn{2}{|c|}{ Phenobarbitone } & \multicolumn{2}{|c|}{ Phetharbital } & \multirow{2}{*}{ Patient's Preference } \\
\hline & & & Sleepiness & Effect on Symptoms & Sleepiness & Effect on Symptoms & \\
\hline $\begin{array}{r}1 \\
2 \\
3 \\
4 \\
5 \\
6 \\
7 \\
8 \\
9 \\
10 \\
11\end{array}$ & $\begin{array}{l}\text { Nil } \\
\text { Nausea, abdominal pain } \\
\text { Headache, Nausea, abdominal pain } \\
\text { Abdominal pain, nausea, headache } \\
\text { Nil } \\
\text { Abdominal pain, nausea, tiredness } \\
\text { Abdominal pain, headache } \\
\text { Lack of concentration, tiredness } \\
\text { Abdominal pain, nausea } \\
\text { Nausea, tiredness }\end{array}$ & $\begin{array}{l}\cdots \\
\cdots \\
\cdots \\
\cdots \\
\cdots \\
\cdots \\
\cdots \\
\cdots\end{array}$ & $\begin{array}{l}\text { Yes } \\
\text { No } \\
\text { Yes } \\
\text { Yes } \\
\text { No } \\
\text { Yes } \\
\text { No } \\
\text { Yes } \\
\text { No } \\
\text { Yes } \\
\text { No }\end{array}$ & $\begin{array}{l}\text { Nil } \\
\text { Nil } \\
\text { Relieved } \\
\text { Nil } \\
\text { Nil } \\
\text { Nil } \\
\text { Nil } \\
\text { Nil } \\
\text { Improved } \\
\text { Nil } \\
\text { Nil }\end{array}$ & $\begin{array}{l}\text { No } \\
\text { No } \\
\text { No } \\
\text { No } \\
\text { No } \\
\text { No } \\
\text { No } \\
\text { No } \\
\text { Ycs } \\
\text { No } \\
\text { No }\end{array}$ & $\begin{array}{l}\text { Nil } \\
\text { Nil } \\
\text { Nil } \\
\text { Nil } \\
\text { Nil } \\
\text { Nil } \\
\text { Relieved } \\
\text { Nil } \\
\text { Nil } \\
\text { Improved } \\
\text { Nil }\end{array}$ & $\begin{array}{l}\text { Phetharbital } \\
\text { Neither } \\
\text { Neither } \\
\text { Phetharbital } \\
\text { Phetharbital } \\
\text { Phetharbital } \\
\text { Phetharbital } \\
\text { Phetharbital } \\
\text { Phenobarbitone } \\
\text { Phetharbital } \\
\text { Phenobarbitone }\end{array}$ \\
\hline
\end{tabular}

Effect in Severe Unconjugated Hyperbilirubinacmia.-A 47-yearold man whose early history was described by Cates and Crawford (1961) has been eleeply jaundiced from birth. Following treatment with phetharbital, initially $300 \mathrm{mg}$ increasing to 900 $\mathrm{mg}$ daily, the plasma bilirubin fell from $16 \mathrm{mg} / 100 \mathrm{ml}$ over 30 days (Fig. 2). Further increase of the dose to $1,200 \mathrm{mg}$ daily reduced

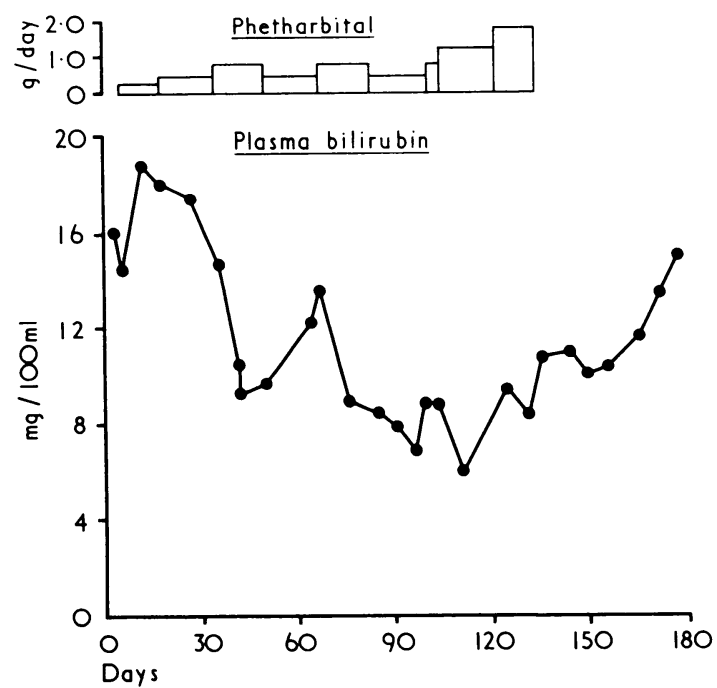
FIG. 2-Effect of various doses of phetharbital on the
plasma bilirubin of a patient with the Crigler-Najiar syndrome (type 2 ).

the level to $6 \mathrm{mg} / 100 \mathrm{ml}$. The plasma bilirubin then began to rise again despite a further increase in dose (Fig. 2). It is possible, however, that the patient was not taking the drug as prescribed, for he has schizophrenia and at times is difficult to manage. When phetharbital was stopped, the plasma bilirubin returned to the original value over the subsequent month.

\section{Discussion}

These results show that $600 \mathrm{mg}$ of phetharbital and $60 \mathrm{mg}$ of phenobarbitone are both highly effective in decreasing the plasma bilirubin of patients with Gilbert's syndrome. The chemical structure of the two drugs is shown in (Fig. 3), and the<smiles>CCCCCCCCCCCCCN1C(=O)NC(=O)C(C)(CC)C1=O</smiles>

Phetharbital<smiles>CCCCCCC1(CC)C(=O)NC(=O)NC1=O</smiles>

Phenobarbitone
FIG. 3-Chemical structure of phenobarbitone and phetharbital. larger dose of phetharbital required is probably a reflection of a more rapid rate of metabolism. Previous workers have claimed that sleepiness caused by phenobarbitone disappears as treatment is continued (Arias et al., 1969; Black and Sherlock, 1970). This was not so in the present patients despite our deliberate choice of a low dose of phenobarbitone, and though in some cases sleepiness was less troublesome it did not disappear. Certainly most of our patients preferred phetharbital to phenobarbitone.

Though both drugs are known to be powerful inducers of hepatic microsomal enzymes, the mechanism by which they reduce the plasma bilirubin in Gilbert's syndrome and other forms of unconjugated hyperbilirubinaemia, including neonatal jaundice (Ramboer et al., 1969), is probably complex. Possible explanations are rendered more difficult because the exact defect responsible for the mild rise in plasma unconjugated bilirubin of Gilbert's syndrome is unknown. The hepatic uptake of infused bilirubin is impaired (Billing et al., 1964; Berk et al., 1970) but this may be a consequence of the deficiency in conjugating enzyme (bilirubin glucuronyl transferase) described by Black and Billing (1969). Both hepatic uptake of bilirubin and enzyme levels have been shown to return to normal after treatment with phenobarbitone $180 \mathrm{mg}$ daily (Black and Sherlock, 1970; Black et al., 1971).

Bile flow also has been shown to be increased in a variety of animals by phenobarbitone, as has liver weight (Klaassen and Plaa, 1968; Berthelot et al., 1970). The latter observation prompted us to measure the liver volume in our patients before and after therapy, using measurements taken from anteroposterior and lateral scintiscans and the formula of Rollo and de Land (1968). In the five patients studied no significant increase could be detected at the end of the four weeks' treatment, the mean volumes being $1,280 \pm$ S.D. $480 \mathrm{ml}$ before and $1,270 \pm$ S.D. $500 \mathrm{ml}$ afterwards. It may be that a longer period of treatment or a larger dose of inducing drug is necessary to increase liver size in man.

Our patient with the more severe unconjugated hyperbilirubinaemia corresponds to the type 2 variety of the CriglerNajjar syndrome as described by Arias et al. (1969). In the type 1 variety, in which glucuronyl transferase is completely absent, the patients have even higher plasma bilirubin levels of 30-40 $\mathrm{mg} / 100 \mathrm{ml}$ and there is no response to phenobarbitone. In the type 2 variety, however, in which there is a partial deficiency of bilirubin glucuronyl transferase, the plasma bilirubin can be lowered by phenobarbitone. Though the risk of kernicterus is probably slight, one case has been described in which the first signs of neurological damage appeared at the age of 16 (Blumenschein et al., 1968). Furthermore, these patients are often worried by the depth of their jaundice, and treatment by phetharbital would appear to be well worth while.

Complaints of vague abdominal pain, nausea, and general malaise are common in Gilbert's syndrome. Indeed 9 of our 11 patients had such symptoms. In only four were these improved by treatment with phenobarbitone or phetharbital and the cause of the symptoms is uncertain. Their severity appeared to be unrelated to the level of the plasma bilirubin and though the symptoms are similar to those of an anxiety state, they do not, in our experience, respond to reassurance or tranquillizing drugs. If symptoms are particularly troublesome, then a short 
course of phetharbital is worth trying, and this may be of value during the exacerbations of jaundice to which these patients are prone, and which may follow alcohol excess or intercurrent infections (Foulk et al., 1959). However, long-term therapy with enzyme-inducing drugs may be harmful, as suggested by the occasional development of osteomalacia in patients with epilepsy, possibly as a result of the induction by anticonvulsants of the hepatic enzymes responsible for the breakdown of vitamin D (Dent et al., 1970). When considering such therapy, even in short courses, for the relief of symptoms in patients with Gilbert's syndrome it would seem reasonable to ensure, by means of a placebo, that any improvement was due to the effect of the inducing drug.

We thank Dr. J. P. Crawford for his help with the case described and Mr. G. R. Davenport, Chief Pharmacist, for preparing the Tables.

\section{References}

Arias, I. M., Gartner, L. M., Cohen, M., Ben Ezzer, J., and Levi, A. J. (1969). American fournal of Medicine, 47, 395.
Berk, P. D., Bloomer, J. R., Howe, R. B., and Berlin, N. I. (1970). American Fournal of Medicine, 49, 296

Berthelot, P., Erlinger, S., Dhumeaux, D., and Preaux A.-M. (1970). American fournal of Physiology, 219, 809

Billing, B. H., Williams, R., and Richards, T. G. (1964). Clinical Science, $27,245$.

Black, M., and Billing, B. H. (1969). New England fournal of Medicine, 280,1266 .

Black, M., Fevery, J., Parker, D., Jacobson, J., and Billing, B. H. (1971). Gastroenterology, 60, 184.

Black, M., and Sherlock, S. (1970). Lancet, 1, 1359.

Blumenschein S. D., et al. (1968). Paediatrics, 42, 786

Cates, B., and Crawford, J. P. (1961). Lancet, 2, 376.

Dent, C. E. Richens, A., Rowe, D. J. F., and Stamp, T. C. B. (1970). British Medical fournal, 4, 69.

Foulk, W. T., Butt, H. R., Owen, C. A., Whitcomb, F. F., and Mason, H. L. (1959). Medicine, 38, 25.

Klaassen, C. D., and Plaa, G. L. (1968). Fournal of Pharmacology and Experimental Therapeutics, $161,361$.

Kuntzman, R., Jacobson, M., Levin, W., and Conney, A. H. (1968). Biochemical Pharmacology, 17, 565.

Millichap, J. G., Hernandez, P., Zales, M. R., Halpern, L. A., and Kramer, B. I. (1960). Neurology (Minneapolis), 10, 575.

Ramboer, C., Thompson, R. P. H., and Williams, R. (1969). Lancet, 1, 966.

Rollo, F. D., and de Land, F. H. (1968). Radiology, 91, 1191.

Thompson, R. P. H. (1969). Fournal of Clinical Pathology, 22, 439.

\section{In-use Evaluation of Safety to Skin of Enzyme-Containing Washing Products}

British Medical fournal, 1971, 2, 499-501

\section{Summary}

The effect on the skin of housewives of using a washing product in the home for all cleaning purposes under conditions of maximal exposure has been studied. Tests conducted on over 4,000 housewives showed that detergents containing proteolytic enzymes had no greater effect on the skin than conventional detergents, even when the hand skin condition was initially poor. The same was true in a further test on 130 housewives with "dishpan" hands. No adverse reactions attributable specifically to the enzyme products were seen. No eruptions from contact with clothes washed in enzyme products were reported from any of the families involved in these tests.

\section{Introduction}

Johnson et al. (1953) described a test which compared changes in the skin induced by washing products when used at home by matched groups of subjects under controlled conditions. The present report describes five such "home-use tests" conducted in the U.K. on enzyme-containing washing products and an additional test on housewives with hands in poor condition. All were conducted under conditions which maximized the effect of exposure to the products.

\section{Materials}

The detergent formulations included both washing and presoak products incorporating $0 \cdot 3-1 \cdot 0 \%$ of enzyme ingredient

\section{Newcastle upon Tyne}

R. MASON BOLAM, M.D., Consultant Dermatologist

Biological Services Group, Product Development Department, Procter \& Gamble Limited, Newcastle upon Tyne NE99 1EL

R. HEPWORTH, Member

L. T. BOWERMAN, B.A., Manager
(Griffith et al., 1969). Most also contained perborate. The enzyme ingredient contained $5-10 \%$ of the pure proteolytic enzyme, a subtilisin of the Carlsberg type (Smith et al., 1968; Keay and Moser, 1969).

\section{Method}

The study was designed to compare the primary irritancy of the washing products under test with that of long-established washing products by observing changes in skin condition over the usage period. Such changes are influenced by individual tolerance, by exposure to all exogenous factors in the home environment, and by any protective measures adopted. The groups using each product were made as identical as possible in respect to all variables except the product. Specifically for each usage period the initial mean skin condition was the same for each group. Subjects were asked not to use hand creams or to wear gloves. All the tests except one were performed between November and March. Working-class subjects were investigated, and they were asked to use the products for all cleansing purposes, including dish-washing and general household cleaning. All tests were performed under strict double-blind conditions; the products were issued in blank, coded cartons and all gradings made without knowledge of previous observations on that subject or of which product was used.

A cross-over design was used, every subject using two products in succession, each for two weeks. Since for each two-week period the mean initial skin condition of both groups was the same, the final mean condition was a measure of tolerance to the product. Up to five products were evaluated in one test, and these always included at least one well-established nonenzyme product.

\section{EXAMINATION}

Objective Assessment.-With a lens (x5) the whole of both hands was assessed for erythema, scaling, and fissuring and a grade assigned on a 10 -point scale, in tens. Very slight scaling 